\title{
In the wake of the comet: remembering Peter Paul Morgan
}

"Living with Peter was like holding on to the tail of a comet." - Wynne Morgan

I was fortunate to land my first job as a copyeditor at $C M A J$, in 1983 . I was even more fortunate that the editor at the time was Dr. Peter Morgan, who died Nov. 8, 2012.

Peter was intelligent, generous, well-read, original and irrepressible, with a quick mind and an appetite for learning and sharing that learning. He was knowledgeable and passionate about writing, particularly scientific writing, and during his tenure as editor (1982-1985) he wrote numerous editorials on scientific writing and style aimed at helping authors become better writers, several of which were collected in his book An Insider's Guide for Medical Authors \& Editors. ${ }^{1}$ It included some of his clever, instructive pieces on word usage and intelligent reading of the scientific literature featuring the fictional Drs. Relso and Lucid. ${ }^{2-4} \mathrm{He}$ was also passionate about accuracy in scientific communication and gave his staff courses in statistics, numeracy, and building tables and graphs, in addition to writing about these topics.

In attending his courses and editing his essays, I learned much about writing, editing, trimming the fat and the importance of using just the right word in the right place. Yes, there is a difference between prevalence and incidence, between accuracy and precision. He often worked on submitted manuscripts himself, hacking out verbiage, inserting new, pithier sentences, and reorganizing the text to clarify the author's message and improve the logic of the argument and the flow of the prose. At many journals, a paper might have been rejected outright because of its length or poor writing, but if the research was sound, Peter helped the author communicate the findings effectively.

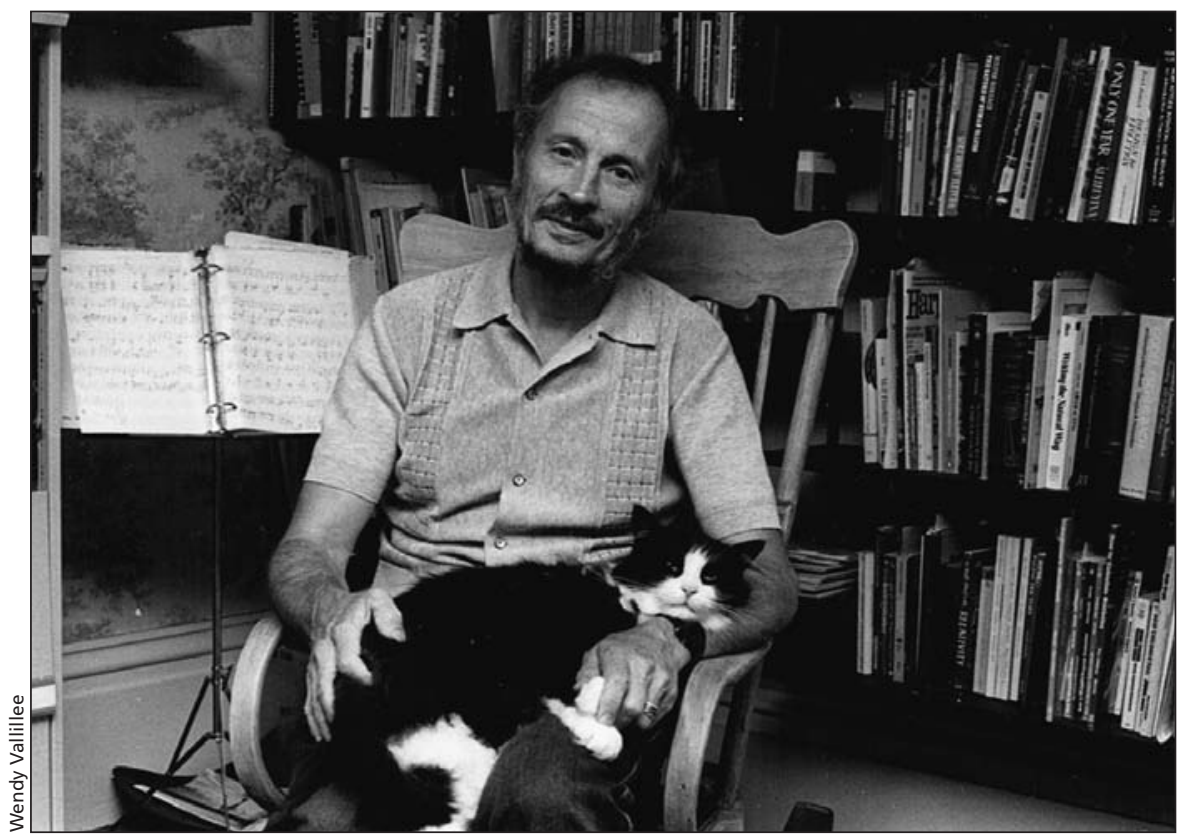

Former CMAJ Scientific Editor Dr. Peter Morgan was truly a renaissance man - a writer, composer, music aficionado and singer, in addition to physician, neurologist, epidemiologist, editor, teacher and lifelong learner. Morgan died Nov. 8, 2012.

Peter sought his staff's opinions at weekly editorial staff meetings, where we would sit in a circle in his small office crammed with books and piles of papers to discuss "problem" manuscripts and to put together issues of the journal. He taught by example that every person - even neophyte assistant editors - had value and something to contribute.

He was in the vanguard of those who recognized the benefits of the emerging computer technology to the editorial office and encouraged its implementation in manuscript processing, tracking, reviewing and editing.

Peter made friends throughout CMA House. One such friend was Kay Methot, who worked in the kitchen. Peter commuted from Toronto during his early days with CMAJ and would leave his supply of food in the kitchen fridge. Recalls Kay, "Peter was a very humble, approachable individual. I loved his sense of humour, his kindness and the fact that he never condescended to anyone." He also enjoyed food from the wild. Ann Bolster, managing editor of CMAJ while Peter was scientific editor, thinks of Peter whenever she's hiking in Gatineau Park in early spring. "The emerald clusters of wild leeks so vivid on the brown forest floor evoke strong olfactory memories. Peter would sometimes bring in this pungent delicacy to munch on while working. We all then knew that Peter was in the house!"

A highlight of the summers was the "Roast and Boil," a corn roast and barbecue that Peter and his wife, Wynne, hosted at their century-old "yellow house on the hill" in Lanark, Ontario. Peter was proud of the village and would give us the tour - the local eatery, the chocolate shop, the baseball field - ending up with a swim in the Clyde River. Peggy Robinson worked with Peter at CMA 
Publications in the 1990s and recollects that he was "an intrepid naturalist, very much interested in the world around him," and would take his colleagues out to explore the nearby fields and woods. In winter, he would invite colleagues out for cross-country skiing and would lead them on one of his personal trails down along the river.

Peter was truly a renaissance man a writer, composer, music aficionado and singer, in addition to physician, neurologist, epidemiologist, editor, teacher and lifelong learner. On one occasion, he was incredulous to learn that I was not familiar with the music of the Finnish composer Jean Sibelius and immediately gave me a mini-course on the topic. He also encouraged my passion, writing and performing songs, and my desire to become a freelance editor. Kay Methot recalls him singing along to the Gilbert and Sullivan music she would sometimes have playing in the kitchen. In his retirement, he was able to complete an opus that he had been working on for many years, an opera entitled Open House, and in 2011, he realized the dream of seeing it staged. He also self-published a fantasy novel, The Words of the Papermaker, under the pseudonym Peter G. Angelin.

Peter and I kept in touch over the years, and I attended his birthday party in 2007, a music-filled affair celebrating his accomplishments over 80 years and attended by what seemed to be all the residents of the Village of Lanark, in addition to friends from the many spheres of his life. The last time I saw him was Canada Day 2011, when I ran into him in the village. Using his walking poles, he had trekked the halfkilometre to the convenience store to get some chocolate for Wynne and was sitting in a tiny park beside the store, enjoying an ice cream cone. We sat chatting and catching up for a while. Then he collected up his poles and doggedly set off toward home.

Godspeed, Dr. Morgan.

Gloria Baker

Former senior assistant editor CMAJ

Acknowledgement: Many thanks to Ann Bolster for her enthusiastic support and helpful suggestions, to Wynne Morgan for providing the photograph and to my CMA colleagues for sharing their memories of Peter.

\section{References}

1. Morgan P. An insider's guide for medical authors \& editors. Philadelphia (PA): ISI Press; 1986.

2. Morgan PP. Dr. Lucid's word rounds: putting in a good word for some good words CMAJ 1985;132: 504-5.

3. Morgan PP. Dr. Lucid's word rounds: introducing IMRAD. CMAJ 1985;133:542-3.

4. Morgan PP. Dr. Lucid's word rounds: IMRAD on the wards. CMAJ 1986;134:209-10.

CMAJ 2013. DOI:10.1503/cmaj.130352 